\title{
PERILAKU PENCARIAN INFORMASI WISATAWAN TERHADAP PEMENUHAN KEBUTUHAN INFORMASI DESTINASI WISATA PANGANDARAN
}

\author{
Agustina Eka Putri ${ }^{1}$, Ute Lies Siti Khadijah ${ }^{1}$, Evi Novianti ${ }^{2,}$ Awaludin Nugraha ${ }^{2}$ \\ ${ }^{1}$ Program Studi Magister Pariwisata Sekolah Pascasarjana Universitas Padjadjaran \\ ${ }^{2}$ Program Studi Ilmu Sejarah Fakultas Ilmu Budaya Universitas Padjadjaran \\ E-mail: agustina19001@unpad.ac.id; ute.lies@unpad.ac.id ; evi.novianti@unpad.ac.id ; \\ awaludin.nugraha@unpad.ac.id
}

\begin{abstract}
ABSTRAK
Tujuan dari penelitian ini adalah untuk mengetahui apakah dan perilaku wisatawan dalam proses pencarian infomasi sebuah destinasi melalui media Instagram mempengaruhi niatnya untuk berkunjung ke destinasi tersebut. Penelitian ini merupakan penelitian kuantitatif dengan metode deskriptif survey. Model yang digunakan dalam penelitian ini adalah infomation search process untuk menggambarkan perilaku dalam proses pencarian informasi sebagai rangkaian dari pikiran, perasaan dan tindakan. Data diperoleh melalui penyebaran kuesioner kepada 200 orang kelompok usia produktif di Kota Bandung yang menggunakan instagram sebagai sarana untuk mencari informasi untuk berwisata. Hasil penelitan menunjukan bahwa cara promosi melalui media sosial (instagram) terbukti lebih efektif menjadi salah satu faktor pendorong minat yang semakin meyakinkan seseorang untuk berkunjung ke Pangandaran disamping promosi yang mereka terima dari media lain atau melalui mulut ke mulut.
\end{abstract}

Kata kunci; visit intention, media social, word of mouth, infomation search process models

\section{BEHAVIOR OF TOURIST INFORMATION SEARCH TO FULFILL INFORMATION ABOUT PANGANDARAN AS TOURISM DESTINASTION}

\begin{abstract}
The purpose of this study is to find out behavior of tourists in the process of finding information about a destination through Instagram influences to up their intention to visit the destination. This research is a quantitative research with descriptive survey method. The model used in this research is information search process models to describe behavior in the process of finding information as a series of thoughts, feelings and actions. Data obtained through the distribution of questionnaires to 200 people of productive age groups in Bandung who use Instagram to finding information for travel. The research results show that the way promotion through social media (Instagram) has proven to be more effective is one of the factors driving interest that is increasingly convincing someone to visit Pangandaran in addition to the promotions they receive from other media or by word of mouth.
\end{abstract}

Key words; visit intention, media social, word of mouth, infomation search process models

\section{PENDAHULUAN}

Kepariwisataan di era otonomi daerah menjadi salah satu faktor penting yang mendukung terhadap penerimaan daerah. Argumen yang mendasari karena mata rantai dari pengembangan kepariwisataan cenderung kompleks, baik secara langsung atau tidak langsung. Oleh karena itu, setiap daerah berkepentingan untuk memacu daya tarik kepariwisataan sehingga menjadi daerah tujuan wisata yang mampu menggerakan basis ekonomi lokal yang bersifat kerakyatan, termasuk juga melakukan renovasi aset-aset wisata.

Pangandaran merupakan salah satu Kabupaten dengan potensi terbesar di sektor pariwisata, yang mana sektor pariwisata ini menjadi sektor unggulan yang menghasilkan pendapatan daerah terbesar bagi Kabupaten Pangandaran. Sampai saat ini terdapat beberapa obyek wisata yang telah menjadi destinasi wisata bagi wisatawan lokal maupun mancanegara, seperti: Pantai Pangandaran, Pantai Batu Karas, Pantai Karapyak, Green Canyon (Cukang
Taneuh), Pantai Batu Hiu, Curug Citumang, Pantai Madasari, Pantai Karang Nini, Curug Bojong, Cagar Alam Pananjung, Pantai Keusik Luhur, Santirah River Tubing, Saung Muara, Desa Wisata Selasari, Pantai Karang Tirta, Goa Sumur mudal dan Air Terjun Curug Jojogan. (Sumber: RIPPARDA Kabupaten Pangandaran Tahun 2016)

Sebagai daerah otonomi baru, tentuya Pemerintah Kabupaten Pangandaran harus berbenah dan melakukan pembangunan di segala sektor. Terutama di sektor pariwisata, karena Pangandaran merupakan daerah dengan potensi pariwisata yang besar tentu harus didukung dengan infrastruktur yang memadai seperti infrastruktur jalan untuk kemudahan akses bagi wisatawan untuk menjangkau tempat tujuan wisatanya.

Informasi menjadi faktor penting dalam perkembangan dunia pariwisata. Tidak bisa dipungkiri, dewasa ini perkembangan teknologi informasi mulai masuk ke berbagai wilayah di Indonesia. Internet merupakan salah satu media 
informasi yang digunakan oleh berbagai macam perusahaan dan instansi, baik instansi pemerintahan ataupun instansi pendidikan dalam memperkenalkan produk atau jasa yang ditawarkan kepada masyarakat. Dinilai dari segi efisiensi dan efektifitasnya internet lebih unggul dibandingkan dengan media informasi lainnya. Salah satu media internet yang digunakan berbasis web site. Banyak sekali web site yang berisi informasi sebagai contohnya sistem informasi. Sistem informasi pariwisata adalah sistem informasi yang dibangun untuk memenuhi kebutuhan informasi wisatawan (Manongga, 2010).

Beberapa hasil penelitian banyak masyarakat yang ingin mencari informasi pariwisata dengan mudah dan cepat tetapi setiap individu memiliki kebutuhan informasi yang berbeda-beda. Belkin (dalam Wiranata, 2010) menyatakan bahwa "kebutuhan dan perilaku pencarian informasi dapat dipengaruhi oleh bermacam-macam sebab, antara lain latar belakang sosial, budaya, pendidikan, tujuan yang ada dalam diri manusia tersebut serta lingkungan sosialnya". Hal ini didukung oleh pernyataan Krech, Crutchfield, dan Ballachey (dalam Yusup, 2010) bahwa timbulnya kebutuhan seseorang tetap dipengaruhi oleh kondisi fisiologis, situasi, dan kognisinya. Teknologi komunikasi yang semakin maju dan berkembang menumbuhkan berbagai pengaruh bagi penggunanya. Teknologi bagai bermata dua yang memberikan kelebihan dan kekurangan. Masyarakat dituntut untuk lebih mampu memanfaatkan teknologi sesuai dengan fungsinya. Internet merupakan bentuk dari perkembangan teknologi yang saat ini sudah menjadi kebutuhan bagi sebagian kalangan. Perubahan zaman yang mengharuskan pengetahuan teknologi dapat digunakan dan dimanfaatkan oleh semua pihak.

Asosiasi Penyelenggara Jasa Internet Indonesia (APJII) mengungkapkan jumlah pengguna internet di Indonesia tahun mencapai 88 juta orang hingga akhir tahun 2017. Berdasarkan populasi, jumlah pengguna Internet terbanyak adalah di provinsi Jawa Barat sebanyak 16.4 juta, diikuti oleh Jawa Timur 12.1 juta pengguna dan Jawa Tengah 10.7 juta pengguna. Perangkat yang digunakan untuk mengakses internet sebanyak $85 \%$ menggunakan telepon seluler, $32 \%$ menggunakan laptop/netbook, $14 \%$ menggunakan PC/komputer, $13 \%$ menggunkan tablet. Menurut Asosiasi Penyelenggara Jasa Internet Indonesia (APJII) bahwa ada tiga alasan utama orang Indonesia menggunakan internet. Tiga alasan itu adalah untuk mengakses sarana sosial/komunikasi (72\%), sumber informasi harian $(65 \%)$, dan mengikuti perkembangan jaman (51\%). Tiga alasan utama mengakses internet itu dipraktikan melalui empat kegiatan utama, yaitu menggunakan jejaring sosial $(87 \%)$, mencari informasi $(69 \%)$, instant messaging $(60 \%)$ dan mencari berita terbaru $(60 \%)$ (www.apjii.or.id).

Saat ini jutaan orang di seluruh dunia bergantung pada media sosial untuk bekerja, bersosialisasi, belajar dan hiburan (Al-Badi et al., 2013; Alenezi et al., 2015). Selain itu, media sosial adalah alat pemasaran utama untuk produk dan layanan karena efektivitasnya dan biaya rendah (AlWahaibi et al., 2015; Nusair et al., 2012). Oleh karena itu, beberapa negara di dunia menggunakan media sosial untuk mengelola dan mempromosikan tujuan dan layanan wisata mereka (Al-Zedjali et al., 2014).

Teknologi komunikasi telah melahirkan beragam media sosial yang telah berkembang pesat yang membuat banyaknya jenis sosial media bermunculan, salah satunya yaitu instagram. Instagram adalah salah satu media sosial yang bisa dikatakan memiliki genre picture publishing, karena keunggulannya dalam mengambil, mengedit serta mengungguah suatu gambar dan konten like (suka), komentar serta following maka bisa dikatakan Instagram adalah jenis media sosial picture publishing. Dengan demikian, di sektor ini, wisatawan atau pengunjung akan sangat tertarik dan terlibat dalam proses pengambilan keputusan, yang akan menghasilkan banyak pencarian informasi dari berbagai sumber yang berbeda (Treer, 2010; Alalwan et al., 2016). Oleh karena itu, media sosial dapat memberikan informasi yang lebih kaya tentang pariwisata untuk membantu wisatawan dalam membuat keputusan.

Tujuan dalam penelitian ini yaitu untuk melihat sejauh mana proses pencarian informasi yang dilakukan oleh pengguna instragram, sehingga mereka dapat menemukan informasi yang seseuai dengan keinginan dan sesuai dengan kebutuhan pencarian informasi kepariwisataan di Kabupaten Pangandaran.

\section{METODE}

Dalam penelitian ini, peneliti menggunakan metode penelitian deskriptif survey. Penelitian deskriptif bertujuan untuk menjelaskan, meringkaskan berbagai kondisi, berbagai situasi atau berbagai variabel yang timbul dimasyarakat yang menjadi objek peneitian itu berdasarkan apa yang terjadi. Kemudian mengangkat kepermukaan karakter atau gambaran tentang kondisi, situasi atau variabel tersebut. Pada umumnya penelitian ini menggunakan statistik induktif untuk menganaisis data penelitiannya.

Peneliti menggunakan metode penelitian deskriptif survey kuantiatatif, karena peneliti ingin memaparkan situasi atau peristiwa yang terjadi pada pola perilaku pencarian pada media media sosial instagram dalam memenuhi kebutuhan masyarakat dalam pencarian informasi pariwisata di Pangandaran.

Populasi dalam penelitian ini adalah masyarakat usia produktif di Kota Bandung yang menggunakan Instagram sebagai sarana untuk pencarian informasi sebelum melakukan kunjungan wisata. Jumlah populasi dapat dilihat dari tabel berikut:

Tabel 1

Jumlah Penduduk Kota Bandung 2018

\begin{tabular}{|c|l|c|}
\hline No & \multicolumn{1}{|c|}{ Kelompok Usia } & Jumlah \\
\hline 1 & $\begin{array}{l}\text { Tidak Produktif }(0-14 \\
\text { Tahun })\end{array}$ & 562.000 jiwa \\
\hline
\end{tabular}




\begin{tabular}{|c|l|c|}
\hline No & \multicolumn{1}{|c|}{ Kelompok Usia } & Jumlah \\
\hline 2 & Produktif(15-64 Tahun) & 1.081 .000 jiwa \\
\hline 3 & $\begin{array}{l}\text { Tidak Produktif (65+ } \\
\text { Tahun) }\end{array}$ & 132.000 jiwa \\
\hline
\end{tabular}

Sumber: Badan Pusat Statistik, 2019

Tabel 2

Jumlah Kelompok Usia Produktif Kota Bandung 2018

\begin{tabular}{|c|c|c|c|}
\hline \multirow{2}{*}{ No } & Kelompok & \multicolumn{2}{|c|}{ Jumlah } \\
\cline { 3 - 4 } & Usia & Laki-laki & Perempuan \\
\hline 1 & $15-19$ tahun & 107.583 jiwa & 109.771 jiwa \\
\hline 2 & $20-24$ tahun & 133.079 jiwa & 124.578 jiwa \\
\hline 3 & $25-29$ tahun & 118.368 jiwa & 109.131 jiwa \\
\hline 4 & $30-34$ tahun & 108.945 jiwa & 100.824 jiwa \\
\hline 5 & $35-39$ tahun & 97.973 jiwa & 96.857 jiwa \\
\hline 6 & $40-44$ tahun & 93.255 jiwa & 93.613 jiwa \\
\hline 7 & $45-49$ tahun & 82.900 jiwa & 85.195 jiwa \\
\hline 8 & $50-54$ tahun & 72.885 jiwa & 74.157 jiwa \\
\hline 9 & $55-59$ tahun & 59.414 jiwa & 61.344 jiwa \\
\hline 10 & $60-64$ tahun & 40.453 jiwa & 39.724 jiwa \\
\hline
\end{tabular}

Sumber: Badan Pusat Statistik, 2019

Sampel adalah bagian dari jumlah dan karakteristik yang dimiliki oleh populasi tersebut (Sugiyono, 2011). Kelompok usia yang diambil menjadi percontohan untuk sampel adalah kelompok usia 20-24 tahun (total 257.657 jiwa) dikarenakan merupakan kelompok usia produktif terbanyak dan tentulah lekat dengan penggunaan media sosial di kehidupan sehariharinya.

Pada penelitian ini teknik sampling yang digunakan yaitu accidental dan quota sampling. Teknik accidental dipilih karena sifat penelitian yang umum serta agar hasil tidak sulit untuk diolah dan dapat dilakukan analisa lebih mendalam dilakukanlah pembatasan (quota) sebanyak 200 orang responden saja yang dianggap telah dapat mewakili populasi.

\section{HASIL DAN PEMBAHASAN}

Landasan teori yang penulis gunakan adalah teori Kuhlthau yaitu Information Search Process (ISP). Model ISP menggambarkan pengalaman pengguna dalam proses pencarian informasi sebagai rangkaian pikiran, perasaan, dan tindakan. Pikiran yang dimulai sebagai pasti, jelas, dan ambigu menjadi lebih jelas, lebih terfokus, dan spesifik sebagai proses pencarian berlangsung. Perasaan cemas dan ragu menjadi lebih percaya diri dan yakin. Melalui tindakan mereka,orang mencari informasi yang relevan dengan topik umum dalam tahap awal dari proses pencarian dan relevan dengan topik terfokus ke arah penutupan. Perumusan fokus atau perspektif pribadi dari topik adalah titik penting dalam proses pencarian. Information Search Process (ISP) adalah model enam tahap pengalaman holistik pengguna dalam proses pencarian informasi.Berikut adalah tahapannya:

1. Inisiasi (tahap awal pencarian), ketika seseorang pertama menjadi sadar dari kurangnya pengetahuan atau pemahaman dan perasaan ketidakpastian dan ketakutan yang umum.

2. Seleksi (tahap pemilihan), ketika topik, atau masalah diidentifikasi dan ketidakpastian awal sering memberikan cara untuk rasa singkat optimisme dan kesiapan untuk memulai pencarian.

3. Eksplorasi (tahap penjelajahan), ketika tidak konsisten, informasi yang tidak kompatibel ditemui dan ketidakpastian, kebingungan, dan keraguan sering meningkat dan orang menemukan diri mereka "di dip" kepercayaan.

4. Formulasi (tahap penyusunan), ketika perspektif terfokus terbentuk dan ketidakpastian berkurang karena kepercayaan mulai meningkat.

5. Koleksi (tahap pengumpulan), ketika informasi yang berkaitan dengan perspektif fokus dikumpulkan dan ketidakpastian mereka sebagai bunga dan keterlibatan memperdalam.

6. Presentasi (tahap penyajian), ketika pencarian selesai dengan pemahaman baru yang memungkinkan orang untuk menjelaskan nya mengajarkan kepada orang lain atau bagaimanapun mendapatkan pelajaran untuk menggunakannya kembali (Kuhlthau, 2013).

Setiap individu memiliki kebutuhan informasi yang berbeda-beda. Belkin (dalam Wiranata, 2010) menyatakan bahwa "kebutuhan dan perilaku pencarian informasi dapat dipengaruhi oleh bermacam-macam sebab, antara lain latar belakang sosial, budaya, pendidikan, tujuan yang ada dalam diri manusia tersebut serta lingkungan sosialnya". Hal ini didukung oleh pernyataan Krech, Crutchfield, dan Ballachey bahwa timbulnya kebutuhan seseorang tetap dipengaruhi oleh kondisi fisiologis, situasi, dan kognisinya (Yusup dan Subekti, $2010: 82$ ).

Sejarah terbentuknya Kabupaten Pangandaran diawali dengan Undang-undang Nomor 21 tahun 2012 yang mendasari lahirnya kabupaten baru atau daerah otonomi baru (DOB), yang ditandatangani oleh Presiden Susilo Bambang Yudhoyono pada tanggal 16 November 2012. Kemudian diundangkan oleh Menteri Hukum dan HAM Amir Syamsudin pada tanggal 17 November 2012, maka Pangandaran resmi menjadi Kabupaten di Provinsi Jawa Barat. Dengan cakupan wilayah meliputi 10 Kecamatan, yaitu: Kecamatan Parigi, Kecamatan Cijulang, Kecamatan Cimerak, Kecamatan Cigugur, Kecamatan Langkaplancar, Kecamatan Mangunjaya, Kecamatan Padaherang, Kecamatan Kalipucang, Kecamatan Pangandaran dan Kecamatan Sidumulih, Ibu Kota Kabupaten Pangandaran berkedudukan di Kecamatan Parigi. Kabupaten Pangandaran memiliki potensi yang besar di bidang Pariwisata, dengan misi Kabupaten Pangandaran adalah "Kabupaten Pangandaran pada tahun 2025 menjadi kabupaten pariwisata yang mendunia, tempat tinggal yang aman dan nyaman berlandaskan norma agama". Letak geografis wilayah Kabupaten Pangandaran berada pada $108^{\circ} 30^{\prime}$ - $108^{\circ} 40^{\prime}$ Bujur Timur dan 7०40'20" - 750’20' 'Lintang Selatan. Jika dilihat pada peta Jawa Barat, Kabuapten Pangandaran 
terletak paling tenggara. Dengan wilayah administratif yaitu:

1. Sebelah Utara berbatasan dengan Kabupaten Ciamis dan Kota Banjar

2. Sebelah Barat berbatasan dengan Kabupaten Ciamis dan Kabupaten Tasikmalaya

3. Sebelah timur berbatasan dengan provinsi Jawa Tengah

4. Sebelah Selatan dengan samudera Indonesia.

Luas wilayah Kabupaten Pangandaran secara keseluruhan mencapai 101.092 Ha. Wilayah selatan Kabupaten Pangandaran berbatasan langsung dengan garis pantai samudera Indonesia yang membentang di 6 Kecamatan dengan panjang garis pantai mencapai 91 $\mathrm{km}$. Berdasarkan perhitungan garis lurus, jarak Kabupaten Pangandaran dengan ibu kota Provinsi Jawa Barat Kota Bandung adalah $211 \mathrm{~km}$. Jumlah penduduk Kabupaten Pangandaran pada akhir Desember 2015 tercatat sebanyak 402.413 orang dengan jumlah laki-laki 202.095 dan jumlah perempuan 200.318 orang.

Berdasarkan penelitian yang telah dilakukan mengenai Mengenai Perilaku Pencarian Informasi Terhadap Pemenuhan Kebutuhan Pariwisata Di Instagram, sebagai berikut:

Bagian pertama dari survei berisi pertanyaan tentang penggunaan situs media sosial dan aplikasi untuk perjalanan domestik di pangandaran, untuk mengukur sejauh mana media sosial digunakan untuk merencanakan perjalanan secara lokal. Ditemukan bahwa $48 \%$ responden menggunakan situs media sosial untuk mengumpulkan informasi, $62 \%$ menggunakannya untuk tujuan hiburan, 54\% menggunakannya untuk pekerjaan atau belajar, dan $37 \%$ menggunakannya untuk tujuan sosialisasi. Selain itu, telah ditunjukkan bahwa ada sejumlah besar orang yang menggunakan situs media sosial untuk mendapatkan informasi dan foto tentang tempat yang ingin mereka kunjungi secara lokal di Pangandaran; ini membuktikan bahwa kebanyakan orang di Pangandaran menggunakan media sosial untuk tujuan pariwisata domestik, dan mereka memiliki kemauan untuk mendorong pariwisata domestik di Pangandaran.

Bagian Kedua menjelaskan lebih dari separuh responden mengatakan bahwa mereka kadang-kadang mengunggah foto dan membagikannya kepada orang lain melalui media sosial setelah kembali dari perjalanan, sedangkan $28 \%$ melakukannya setiap saat, sedangkan $16 \%$ dari mereka tidak pernah menggunakan media sosial untuk mengunggah foto. Kebanyakan orang lebih suka menggunakan WhatsApp dan Instagram untuk berbagi foto dengan orang lain. Mengunggah dan berbagi foto tempat di Pangandaran melalui media sosial berpotensi menjadi cara paling ampuh untuk mendorong pariwisata domestik di Pangandaran. Namun, dalam menjawab pertanyaan "Apakah pengalaman negatif atau buruk tentang tujuan perjalanan yang diposting di situs media sosial memengaruhi keputusan perjalanan Anda?" $54,5 \%$ mengatakan mereka bisa dipengaruhi dalam keputusan perjalanan mereka dengan posting negatif ini, $15,9 \%$ mengatakan bahwa mereka pasti terpengaruh, sedangkan 13\% mengatakan mereka tidak, dan 15,9\% mengatakan mereka tidak tahu. Dengan demikian akan terlihat bahwa kebanyakan orang tertarik pada informasi dan foto yang diposting di situs media sosial, dan juga dipengaruhi dalam keputusan perjalanan mereka oleh pengalaman negatif atau buruk tentang tujuan perjalanan yang diposting di situs media sosial. Jelas dari hasil bahwa dari mulut ke mulut memiliki peran penting dalam pengambilan keputusan dalam pariwisata. Dari hasil penelitian ini ditemukan beberapa hasil sebagai berikut:

1. Pada tahap pencarian informasi, masyarakat telah mengetahui tentang informasi pariwisata yang mereka inginkan, mereka akan langsung melakukan pencarian informasi dimedia sosial instagram dengan menggunakan fasilitas explore. Oleh karena itu, dapat disimpulkan semakin mahasiswa mengetahui tentang informasi yang mereka inginkan, mereka akan langsung melakukan pencarian informasi dimedia sosial instagram. Dengan demikian, dapat dikatakan bahwa semakin mereka tahu informasi pariwisata yang mereka inginkan maka, kebutuhan informasi mereka akan terpenuhi.

2. Pada tahap pemilihan informasi, masyarakat mencari informasi tentang perkembangan fashion yang didasari oleh rasa ingin tahu mereka. Dengan demikian, dapat disimpulkan bahwa semakin pandai mereka memilih informasi yang mereka inginkan maka, kebutuhan informasi mereka akan terpenuhi. Selain itu, dalam akun instagram selalu melakukan pembaruan informasi pada waktuwaktu tertentu. Serta adanya testimoni dan beragamnya akun instagram yang menampilkan pariwisata pangandaran membuat mereka merasa dapat terpenuhinya informasi yang mereka butuhkan.

3. Pada tahap penjelajahan informasi, masyarakat banyak mendapatkan informasi awal dari informasi yang beredar di instagram, yang selanjutnya secara seksama mereka melakukan pencarian tentang informasi yang sedang mereka butuhkan tersebut sesuai dengan kebutuhan mereka. Sehingga pada praktiknya mereka menemukan adanya kendala yaitu dengan terlalu banyaknya pilihan akun pariwisata tentang pangandaran di instagram. Oleh karena itu, dapat disimpulkan bahwa semakin pandai mereka menjelajahi informasi maka, kebutuhan informasi mereka akan terpenuhi. Adanya kendala saat berlangsungnya proses pencarian informasi yang dilakukan oleh masyarakat membuat mereka tidak langsung mengikuti (follow) akun-akun pariwisata tentang pangandaran di instagram tersebut. Mereka hanya mengikuti beberapa akun pariwisata saja yang menurut mereka sesuai dengan kebutuhan mereka kedepannya.

4. Pada tahap penyususnan informasi, masyarakat akan mencari tahu testimoni wisatawan 
sebelumnya di beberapa akun pariwisata tentang Pangandaran di instagram. Selanjutnya mereka akan melihat aktfitas apa yang ditawarkan oleh akun instagram tersebut. Namun terlepas dari pencarian yang telah dilakukan sebelumnya masyarakat cenderung tetap mempercayai akun pariwisata tentang Pangandaran di instagram yang mereka temukan dengan informasi yang lengkap walaupun dalam akun tersebut mereka tidak mencantumkan komentar dari pengunjung sebelumnya. Sehingga dapat disimpulkan bahwa semakin banyak informasi dan komentar dari wisatawan sebelumnya yang datang berkujung yang dapat mereka temukan maka kebutuhan informasi mereka akan terpenuhi.

5. Pada tahap pengumpulan informasi, masyarakat telah menemukan informasi destinasi wisata yang sesuai dengan kebutuhanya, mereka akan melakukan screen shoot gambar dan informasi atau akun pariwisata tentang Pangandaran di instagram tersebut, lalu akan menyimpannya kedalam galeri handphone mereka. Hal ini menunjukan bahwa semakin pandai mereka mengumpulkan informasi yang mereka butuhkan maka, kebutuhan informasi mereka akan terpenuhi.

6. Pada tahap penyajian informasi, mereka menemukan informasi destinasi wisata yang sesuai dengan kebutuhan mereka, selanjutnya mereka akan menyebarluaskan informasi tersebut melalui beragam media sosial yang mereka miliki dengan cara screen shoot foto yang mereka temukan, lalu dibagikan melalui beragam media sosial. Informasi yang mereka temukan digunakan untuk melakukan perbandingan antara destinasi sejenis dan melakukan diskusi dengan teman atau kerabat mereka. Hal ini menunjukan bahwa, semakin banyak informasi yang mereka sebarkan atau bagikan kepada kelompok yang ada diberbagai media sosial untuk berdiskusi maka, kebutuhan informasi mereka akan terpenuhi. Hal ini dikarenakan mereka banyak mendapatkan pendapat dari teman atau kerabat.

\section{SIMPULAN}

Dari berbagai sarana penyedia informasi, media sosial utamanya Instagram menjadi pilihan utama dan menjadi salah satu acuan bagi masyarakat khususnya generasi muda (usia produktif) dalam mencari dan menilai sebuah destinasi wisata. Kebiasaan untuk melihat-lihat konten penuh visual penuh warna dan kemudahan interaksi yang disediakan oleh instagram menjadi salah satu keunggulannya dan menjadi faktor pemicu untuk melakukan sebuah perjalanan. Hal ini membentuk sebuah pola perilaku tersendiri. Pangandaran adalah salah satu dari sekian destinasi di Provinsi Jawa Barat yang memiliki keindahan tersendiri yang sering di unggah pada instagram sehingga menarik hati dan menjadi salah satu pilihan generasi muda untuk berlibur. Terbukti promosi dan pencarian informasi melalui instagram lebih efektif menjadi salah satu faktor pendorong minat yang semakin meyakinkan seseorang untuk berkunjung ke Pangandaran disamping promosi yang mereka terima dari media lain atau melalui mulut ke mulut.

\section{DAFTAR PUSTAKA}

Al-Badi, A. H., Okam, M. O., Al Roobaea, R., \& Mayhew, P. J. (2013). Improving usability of social networking systems: a case study of LinkedIn. Journal of Internet Social Networking \& Virtual Communities, 17-23.

Al-Wahaibi, H. A., Al-Mukhaini, E. M., Al-Badi, A. H., \& Ali, S. (2015, February). A case study of the employment of social media in government agencies in Oman. In GCC Conference and Exhibition (GCCCE), 2015 IEEE 8th (pp. 1-6). IEEE.

https://doi.org/10.1109/ieeegcc.2015.7060089

Al-Zedjali, K. H., Al-Harrasi, A. S., \& Al-Badi, A. H. (2014). Motivations for Using Social Networking Sites by College Students for Educational Purposes. World Academy of Science, Engineering and Technology, International Journal of Social, Behavioral, Educational, Economic, Business and Industrial Engineering, 8(8), 25772580

Bungin, Burhan. 2013. Metode penelitian sosial \& ekonomi: format-format kuantitatif dan kualitatif untuk studi sosiologi, kebijakan, publik, komunikasi, manajemen, dan pemasara edisi pertama. Jakarta: kencana prenada media group.

Jaya, Hendra. 2012. Pengembangan Laboratorium Virtual Untuk Kegiatan Praktikum Dan Memfasilitasi Pendidikan Karakter Di SMK. https://journal.uny.ac.id

Kuhlthau, 2013. Guided Inquiry: Learning in the 21st Century. [Online]. Tersedia di: http://cissl.rutgers.edu/guided_inquiry/introductio n. Diakses tanggal 10 Oktober 2019

Manongga, Danny. Samuel Papilaya, Selfiana Pandie. 2010. Sistem Informasi Geografis Untuk Perjalanan Wisata Di Kota Semarang. Jurnal Informatika ed. 10.

Sugiyono, 2011. Metode Penelitian Pendidikan. Bandung: Alfebeta

Yusup dan Subekti, 2010. Teori dan Praktik Penelusuran Informasi (Information Retrieval), Jakarta: Kencana

Yusup, 2010. Pedoman Praktis Mencari Informasi, Bandung: Remaja Rosdakarya Bandung.

Undang-undang:

Rencana Induk Pembangunan Kepariwisataan Daerah (RIPPARDA) Kabupaten Pangandaran Tahun 2016

Lainnya:

Badan Pusat Statstik (BPS). 2019. Jumlah Penduduk Kota Bandung Menurut Kelompok Usia 2018. Diakses dari:

https://databoks.katadata.co.id/datapublish/2019/0

9/17/berapa-jumlah-penduduk-kota-bandung 